\title{
ART
}

\section{ХУДОЖНІЙ ОБРАЗ ПЕРПЕТУУМ МОБІЛЕ В СОНАТІ ДЛЯ ВІОЛОНЧЕЛІ ТА ФОРТЕПІАНО Б. БPITTEHA}

\author{
Борисенко Тетяна Вікторівна, \\ Київ, Украӥна \\ викладач камерного ансамблю Київької муніципальної академії музики ім. Р. М. Гліера, \\ аспірант кафедри академічного і естрадного вокалу та звукорежисури \\ Національної академії керівних кадрів культури і мистецтв
}

DOI: https://doi.org/10.31435/rsglobal_ijitss/31102019/6754

\section{ARTICLE INFO}

Received 19 August 2019

Accepted 20 October 2019

Published 31 October 2019

\section{KEYWORDS}

artistic image, perpetuum mobile, sonata,

cycle,

coolness.

\begin{abstract}
Perpetuum mobile is a multi-valued cultural phenomenon, it symbolizes continuous movement. In contrast to the mechanistic movement aimed at overcoming space, the perpetuum mobile coincides with the concept of movement in philosophy. Even the ancient philosophers knew that the world is constantly moving, changing (Heraclitus). Modern scientists, in particular J. Deleuze, interpret movement as "events" that reflect the interaction of bodies, but are not bodies themselves. In culture, the perpetuum mobile is understood as an image created by certain means of expressiveness in different types of art and has a generalizing character. Among its signs are symbolism, incompleteness or repeatability, non-orientation, cyclicity. The perpetuum mobile is embodied as a sound image in musical works (or its parts) and is manifested at the syntactic and compositional levels of organization of musical material. The article describes the features of the embodiment of the perpetuum mobile in Sonata for cello and piano by Benjamin Britten.
\end{abstract}

Citation: Борисенко Тетяна Вікторівна. (2019) Khudozhnii Obraz Perpetuum Mobile v Sonati dlia Violoncheli ta Fortepiano B. Brittena. International Journal of Innovative Technologies in Social Science. 7(19). doi: $10.31435 /$ rsglobal_ijitss/31102019/6754

Copyright: (c) 2019 Борисенко Тетяна Вікторівна. This is an open-access article distributed under the terms of the Creative Commons Attribution License (CC BY). The use, distribution or reproduction in other forums is permitted, provided the original author(s) or licensor are credited and that the original publication in this journal is cited, in accordance with accepted academic practice. No use, distribution or reproduction is permitted which does not comply with these terms.

Вступ. Перпетуум мобіле - багатозначне культурне явище, що символізує безперервний рух. На відміну від механістичного руху, який спрямований на подолання простору, перпетуум мобіле збігається з поняттям руху у філософії. Іще давнім філософам було відомо, що світ постійно рухається, змінюється (Геракліт). Сучасні науковці, зокрема Ж. Дельоз рух трактують як «події», які відображають взаємодію тіл, але самі не є тілами [6]. В культурі перпетуум мобіле усвідомлюється як образ, що створюється певними засобами виразності в різних видах мистецтва та має узагальнюючий характер. Серед його ознак символічність, незавершеність або повторюваність, не направленість, циклічність. Образ у мистецтві - «узагальнене художнє відображення дійсності, що втілене у форму конкретного індивідуального явища» [3]. Перпетуум мобіле втілюється як звукообраз в музичних творах (або його частинах) і виявляється на синтаксичному та композиційному рівнях організації музичного матеріалу. А саме: в пульсації однакових тривалостей в мелодії або акомпанементі, через монотематизм, циклічність як формотворчий принцип, остинатність, підпорядкованість безперервному наскрізному темпу.

Мета дослідження. Окреслити особливості втілення образу перпетуум мобіле у Сонаті для віолончелі та фортепіано Бенджаміна Бріттена. 
Методологія грунтується на комплексному міждисциплінарному підході 3 інтегруванням методів культурології та мистецтвознавства. Сонологічний метод поєднав філософські, культурологічні та музикознавчі інтенції для визначення ролі звукообразу перпетуум мобіле у загальній концепції творів. Емпіричний метод дозволив виявити музичні образи перпетуум мобіле. Метод структурного та семантичного аналізу дозволив окреслити художньо-образні втілення перпетуум мобіле. Компаративний аналіз - при виявленні спільних та різних рис перпетуум мобіле у музиці та інших видах мистецтва.

Основний зміст. Музичні твори під назвою «Перпетуум мобіле» спершу писалися романтиками у ХІХ ст. Ці твори зустрічаються у творчому доробку Ш. В. Алькана, Ц. Кюї, Ф. Мендельсона, Ф. Пуленка, Ф. Шопена, Ф. Шуберта, Р. Шумана та ін. Образ перпетуум мобіле на той час був втіленням пантеїстичного руху.

Художній образ перпетуум мобіле у ХX ст. набуває нових рис. Жорсткі воєнізовані конфлікти і протистояння в світі знайшли відбиття у культурних і мистецьких процесах. Цим i зумовлена зміна кудожнього наповнення образу перпетуум мобіле. В творчості європейських митців в першій половині XX ст. поширюються образи військової машини, направленої проти людства (Б. Бріттен, Б. Барток, М. Равель, А. Онеггер, І. Стравінський, А. Шнітке, Д. Шостакович).

Для Б. Бріттена перпетуум мобіле є типовим образом у камерно-інструментальних творах. Наприклад, фінали Сюїти для скрипки та фортепіано ор. 6 (1935), Сонати для віолончелі та фортепіано (1961) ор. 65, сюїти для віолончелі № 1 ор.72 та ін. Б. Бріттена мають назву «Перпетуум мобіле» та мають риси техногенної остинатності. Камерна музика була для композитора експериментальною платформою, на якій він випробовував засоби виразності, які потім мали застосування в творах більш великих складів. Для кожного твору автор реалізує особливу структурну та композиційну форму, яка виникла внаслідок творчого перетворення декількох жанрових джерел. Тому в його циклах немає стабільної традиційної кількості частин. Натомість, в його інструментальних циклах назви розділів та жанри повторюються. Це стосується як раннього, так і зрілого етапів творчості композитора. В різних камерних циклах Б. Бріттена зустрічаються: ноктюрни, марші, танці, вокально-жанрові частини. Особливо композитор виділяв фінали - безперервний рух означений автором «Perpetuum Mobile» (або на кшталт твору Н. Паганіні «Moto Perpetuo»). Щоб усвідомити художню значимість даного образа в циклі композитора, розглянемо Сонату для віолончелі та фортепіано ор.65. В цьому визначному творі відбулося не тільки втілення сонатного алегро, але й помітні риси циклічної форми (п’ять частин), сполучення різних жанрових джерел та варіаційність в розвитку.

В циклі назви частин формують принцип програмності твору: «Діалог», «Scherzo Pizzicato», «Елегія», «Марш», «Moto Perpetuo». Перегляд назв частин та означення їх темпів дає попереднє уявлення про розподіл руху у творі. Відверто повільною є тільки центральна «Елегія». Розподіл темпів між частями (2 перші рухливі, 3-тя повільна, 4-5 швидкі) дає підстави вбачати в цьому циклі приховану тричастинність. На підтвердження цієї думки працює і розподіл часу (хронометраж) частин в творі. «Діалог» триває 8 хв. Перша частина стає змістовним центром, відштовхуючись від якого відбувається розгортання концепції твору в наступних частинах. Він безперечно є головною філософською і змістовно-концептуальною основою для розвитку всього циклу, втілює сферу особистого, людяного, того, що з розвитком музики в циклі втрачається. Глибинний інтимний діалог, в прозорій фактурі якого відчувається близькість і взаєморозуміння між двома людьми. У мистецтвознавство поняття діалогу потрапляє 3 лінгвістики. В літературознавстві - це: 1) розмова, низка висловлювань двох або більше осіб на певну тему; 2) у переносному значенні - вільний обмін думками, перемовини [2]. Поняття «діалог» в музиці є традиційним, часто зустрічається в побудові музичної форми, дається як противага монологу, що реалізовано і в даній сонаті.

У першій частині Сонати діалог між короткими репліками віолончелі і акордами фортепіано відбувається у першій темі головної партії [1]. Обидва інструменти наділяються автором різними майже людськими характерами. Збудженість секундових інтонацій віолончелі заспокоюють приглушені м які акорди фортепіано. Перша частина написана в сонатній формі. Головна та побічна партії контрастні за характером. Частина побудована структурно чітко та прозоро. Кожен ii розділ має чіткі контури. Традиційно для сонатного циклу, «Діалог» завершується стрімким фіналом. Тут зберігається і властивий сонатній формі темповий контраст між структурними частинами. Лапідарність гармонії, декламаційність в партії віолончелі характеризують музику цієї частини. 
Надалі в розвитку «розмови» жваво змінюються інтонації висловлювань. Чергування схвильованих і заспокійливих інтонацій створюють характер спілкування людей, що обговорюють дуже зворушливу тему. В другій темі відбувається бурхливе вивільнення експресії, яке досі стримувалося. Друга тема головної партії є бурхливою, схвильованою. Після скупих реплік першої теми вона ллється як експресивний потік емоцій і сприймається як довгоочікуване відверте висловлювання. Розробка будується на хвильовому динамічному розвитку. Реприза - врівноважена та спокійна. Вона завершується кодою, що повертає звучання першої теми головної партії. Головна роль в ній відводиться фортепіано замість віолончелі в експозиції. Побічна партія проводиться в новій тональності F-dur, що надає світлішого забарвлення темі. В Коді органний пункт на тоніці створює характер спокійного завершення діалогу.

Друга частина «Scherzo-pizzicato» триває 3 хв. За гротескним характером попереджає появу «Маршу» (2 хв) i «Moto Perpetuo» (5,5 хв). Не зважаючи на зовнішню ефектну колористику, ця частина насторожує своєю колкістю та ворожістю, занурює слухача у цілком нову образну сферу. Скерцо написано в остинатному гострому ритмі, в складній трьох частинній формі (А-А1-В-А2). Характер першої теми витриманий в іронічній манері підколювання та глузування. Висхідні та низхідні переривчасті трьох звучні мотиви проводяться у віолончелі і у фортепіано. Ці інтонації перекликаються 3 основною темою першої частини «Діалогу». Тема середнього розділу, рухаючись по звукам мажорної гами вверх i мінорної вниз, має заспокійливий характер. «Scherzo-pizzicato» - прохідна між «Діалогом» $\mathrm{i}$ наступною, яка є глибоко трагічним ядром всього твору.

«Елегія» - лірична та заглиблена в роздуми. М. Ростропович (якому присвячений цей твір) писав про неї, як про глибоко драматичну музику [4]. Медитативно-рефлексивна велика центральна частина відтворює занурення у внутрішні суперечності та вагання. Потужна кульмінація підноситься як емоційно-експресивна сповідь. Якщо в першій частині присутні дві особи, ми чуємо їх діалог, то «Елегія» - це рефлексивний монолог одинокої особистості. Частина дуже вагома (6 хв). «Марш» вривається в сутінковий простір після «Елегії» різким квінтольним затактом у віолончелі та пунктирним ритмом дисонуючих акордів у рояля. Контраст низького тембру віолончелі та трубного окличного акцентованого мотиву фортепіано в скляному звучанні (третя октава) одразу демонструють гротескний, механістичний характер теми. Квадратний маршовий метр поєднується 3 дрібним непарним дробленням в мелодиці. В першій темі розділу А це квінтолі в партії віолончелі. Вони складають враження пружин, які з одного боку запускають механізм маршу, а з іншого наче прагнуть вирватись 3 його сталевого каркаса. Засоби виразності, застосовані композитором у цій частині створюють карикатурні, гіперболізовані образи. В середньому розділі В на фоні теми Dies Irae, яка викладена в басу у рояля (pesante) з тріольною репетицією кожного мелодійного звука 3"являються хвалькуваті висхідні зойки з єхидним присвистом у віолончелі. Образи маршу надзвичайно зримі. Ця тема викликає асоціацію 3 солдатами, що маршують та викидають вверх свою зброю або військові атрибути. Так у музиці оживають образи британської політичної карикатури, яка бере початок в роботах майстрів XVIII ст. Джеймса Гілрея, Томаса Роуландсона, Джорджа Крукшенка і продовжується в наступних епохах, особливо в XX ст.. Британський щотижневий журнал гумору та сатири «Панч» 31841 р. до початку XXI ст. був культовим виданням політичної карикатури. Тому зрозуміло, що для британського композитора карикатура була одним з природних проявів менталітету.

Соната для віолончелі та фортепіано ор. 65 писалась Б. Бріттеном майже водночас зі знаменитим «Військовим реквіємом» ор. 66 (1962). Як зазначалось раніше, камерна музика була полем експериментів для випробування творчих ідей композитора. Тому, порівнявши тематизм середнього епізоду «Маршу» та основну тему частини «Dies Irae» «Військового реквієму», визначено спільне: тріольні репетиції, квартовий скачок - трубний Tuba mirum. Попри те, що оркестрові та ансамблеві колористичні можливості різні та й твори загалом несуть відмінні концепції, антимілітаристське направлення «Маршу» стає очевидним.

В репризі тема маршу переноситься в верхній регістр. Тембр віолончелі sul ponticello, гліссандо та свист флажолетів звучать як з потойбіччя. Примарний моторошний епізод, в якому маршовики наче перейшли рису цього світу і продовжують ходу перпетуум мобіле вже у вигляді скелетів. Марево, в якому все зникає з глісандо рояля в коді, водночас зберігає остинатний темп до кінця, навіть без традиційного сповільнення в кінці частини (авторська позначка senza rallentando в останніх двох тактах). Безперервний рух, який наскрізним незмінним темпом пронизує всю 
частину, є символічним, і навіть Судний день (Dies Irae) його не спиняє. Відзначено, що «Марш», завдяки своєму невблагальному руху, втілює образ перпетуум мобіле.

Фінал «Moto Perpetuo» відображає тенденцію автора до втілень образів безперервного руху в фіналах циклів. Варіаційна форма підпорядкована наскрізному стрімкому плину від початкової теми до фінальної кульмінації. Частина продовжує безперервний рух «Маршу», оскільки основна тема перпеетуум мобіле підхоплює тріольний рух вісімками, який виник в середньому розділі попередньої частини. Розмір шість восьмих і темп presto стають основою перпетуум мобіле фіналу. Розподіл на цифри в цій частині відповідає умовній диференціації на варіації.

В тематичному розвитку фіналу виділяються два основних джерела. Це власне, тема перпеетуум мобіле. Вона викладена спочатку у віолончелі тріольними вісімками 3 двома шістнадцятими, шо наче підстрибують. Другий елемент звучить спочатку в акомпанементі. В акордовому супроводі фортепіано виокремлюється низхідна мала секунда, яка семантично завжди асоціювалась із лакримозо або зітханням. Якщо спершу вона в тіні, бо увага слухача прикута до енергії руху віолончелі, то згодом відбувається перерозподіл функцій між інструментами. Тепер у рояля звучить тема перпетуум мобіле, а у віолончелі виразно чути три зітхання, після чого вона знову вступає в процес руху. Варіаційний вир «Moto Perpetuo» демонструє різноманітну образність, яку умовно можна розподілити за гендерними ознаками. Якщо основна тема перпетуум мобіле явно чоловічого характеру, то їі ж варіація з авторськими позначками leggiero та con eleganza втілює примхливу іронічну жіночність. Нова тема соло в партії рояля має в основі мотив «зітхання», про який йшлося вище. Він виникає у високому регістрі на фоні прозорого акомпанементу інтервалами, кружляс серпантином, поступово знижуючись по секундовим інтонаціям. Звучання іï переривається вторгненням теми перпеетуум мобіле на forte у віолончелі. На неї накладається мотив «зітхання». Тепер він виконується фортепіано подвійними октавами в унісон. Його характер в корні змінюється, тепер він акцентовано скандується, що звучить вже як SOS, крик про допомогу. Не отримавши відповіді, фортепіано підхоплює закінчення теми перпетуум мобіле на fortissimo. Нове звучання епізоду con eleganza забезпечується зміною функцій інструментів. Останнім проявом людського начала в фіналі є серпантинна тема, яка тепер виконується віолончеллю в супроводі акордів з низхідною секундою у рояля. Завершує частину всепоглинаюча потужна динамічна хвиля перпеетуум мобіле, яка нарощується від трьох ріano до tutti fortissimo обох інструментів, які зливаються в невблаганному темпі перпетуум мобіле.

Дві останні частини поєднані за принципом безперервного руху. I «хвацький» нахабний марш і перпетуум мобіле в фіналі не лишають ніякої надії на порозуміння між людиною та навколишнім ворожим світом.

Висновки. Дослідження Сонати для віолончелі та фортепіано ор. 65 Б. Бріттена окреслило особливості форми, що має ознаки сюїти. Визначено, що у семантичних джерелах тематизму та формотворчих принципах втілений розподіл на дві основні образні сторони інтимно духовне та вороже бездуховне, механістичне. Контраст між частинами твору демонструє протиставлення суто людського начала в «Діалозі» та глибоке занурення у внутрішній складний світ людини в «Елегії» нездоланному безжальному руху оточуючого світу в «Скерцо», «Марші» та «Moto Perpetuo». Образ перпетуум мобіле в фіналі сонати реалізований через контрастну гендерну полюсність, розвивається на варіаційних засадах. Дві останні частини з'єднані безперервністю руху. «Марш» має гротескне карикатурне забарвлення. Завдяки введенню композитором символів Dies Irae, Tuba mirum, характерних для реквієму, образ перпетуум мобіле останніх двох частин набуває рис антимілітаристського протесту. Фінал «Moto Perpetuo» має зловісний, непоборний, всепоглинаючий характер.

\section{ЛІТЕРАТУРА}

1. Бриттен Б. Соната для виолончели и фортепиано. Москва: Музыка, 1974, 41 с.

2. Великий тлумачний словник сучасної української мови (з доп. I допов.) /Уклад і гол.ред. В. Бусел. Київ, Ірпінь:ВТФ Перун, 2005. С.302

3. Герчанівська П. Культурологія. Термінологічний словник. Київ:НАККіМ, 2015. С 328.

4. Ковнацкая Л. Прокофьев и Бриттен (об исторических паралелях, влиянии и реминисценциях) Отражения музыкального театра в двух книгах. Сборник статей и материалов к юбилею Л. Г. Данько. Санкт-Петербург: Канон, 2001. Кн. 2 С. 50-69.

5. Назайкинский Е. Стиль и жанр в музыке. Москва: ВЛАДОС, 2003. 248 с.

6. Філософський енциклопедичний словник. Гол.ред. В. Шинкарук. Київ: Абрис, 2002 C.558-559 